\title{
Mineral nutrient concentrations in sapwood and heartwood: a literature review
}

\author{
Pierre Meerts* \\ Laboratoire de Génétique et Écologie végétales, Université Libre de Bruxelles, Chaussée de Wavre 1850, 1160 Bruxelles, Belgium
}

(Received 18 January 2002; accepted 8 April 2002)

\begin{abstract}
Patterns in mineral nutrient concentrations in sapwood and heartwood are investigated from published data for N, P, K, Ca and Mg in 22 species of Gymnosperms and 71 species of Angiosperms. The average value of heartwood/sapwood concentration ratio is element-specific, increasing in the following order: $\mathrm{P}(0.36)<\mathrm{N}(0.76)<\mathrm{K}(0.78)<\mathrm{Mg}(1.20)=\mathrm{Ca}(1.25)$. Concentrations of $\mathrm{P}, \mathrm{N}$ and $\mathrm{K}$ are mostly lower in heartwood compared to sapwood. Large variation exists in the concentration pattern of $\mathrm{Ca}$ and $\mathrm{Mg}$, whose functional significance is unclear. A phylogenetic pattern is confirmed, Gymnosperms having lower mineral nutrient concentrations in wood compared to Angiosperms, most strikingly so for $\mathrm{N}, \mathrm{K}$ and $\mathrm{Mg}$ in sapwood. Heartwood and sapwood concentrations are positively correlated across species, and species with nutrient-poor sapwood have disproportionately poorer heartwood. The results are discussed in relation to the hypothesis that mineral nutrients are recycled from senescing sapwood.
\end{abstract}

wood / mineral nutrient concentration / translocation / resorption efficiency / Gymnosperms / Angiosperms

Résumé - Concentrations en éléments minéraux dans le bois de cour et l'aubier : une revue de la littérature. Les patrons de variation des concentrations en N, P, K, Ca et Mg dans le bois de cœur et l'aubier sont analysés à partir de données de la littérature se rapportant à 22 espèces de Gymnospermes et 71 espèces d'Angiospermes. Le bois de cœur est le plus souvent plus pauvre en N, P et K que l'aubier. Les rapports de concentration cour/aubier varient selon l'élément, dans l'ordre suivant : $\mathrm{P}(0,36)<\mathrm{N}(0,76)<\mathrm{K}(0,78)<\mathrm{Mg}(1,20)=\mathrm{Ca}(1,25)$. De grandes variations existent dans le patron de concentration en $\mathrm{Ca}$ et $\mathrm{Mg}$, dont la signification fonctionnelle n'est pas claire. Un patron phylogénétique est confirmé : le bois des Gymnospermes est plus pauvre en éléments minéraux, particulièrement pour $\mathrm{N}$, Mg et $\mathrm{K}$ dans l'aubier. Les concentrations dans le cœur et dans l'aubier sont corrélées positivement, et les espèces à aubier pauvre tendent à avoir un cœur appauvri de façon disproportionnée. La discussion examine la cohérence des résultats avec l'hypothèse selon laquelle des éléments minéraux sont résorbés au moment de la formation du bois de cœur.

bois / concentration en éléments minéraux / translocation / efficacité de résorption / Gymnospermes / Angiospermes

\section{INTRODUCTION}

Mineral nutrients are limiting resources to plants and the allocation and translocation of mineral nutrients among different organs are important mechanisms enhancing nutrient use efficiency in plants $[3,25,37,55,65]$. It is commonplace that different plant organs have vastly different mineral element concentrations. In trees, wood usually has the lowest mineral nutrient concentration of all organs [24, 26, 70, 74]. However, wood itself is not necessarily homogeneous with respect to mineral element concentrations [14, 32, 54]. Daube
(1883) cited in [9] was the first to report higher mineral nutrient concentrations in sapwood compared to heartwood. Computations of mineral element budgets and fluxes in forest stands need to allow for differences in mineral nutrient content between sapwood and heartwood [6, 7, 15, 16, 19, 62, 71].

In woody organs, the outermost wood layers that contain living cells are referred to as sapwood. In most if not all, tree species, inner sapwood rings are eventually converted into heartwood. Heartwood no longer contains living cells, often has vessels blocked with tyloses and can accumulate

\footnotetext{
* Correspondence and reprints

Tel.: (+32) 26509 167; fax: (+32) 26509 170; e-mail: pmeerts@ulb.ac.be
} 
secondary compounds $[9,27,32,60,67,77]$. The cause and function of heartwood formation are disputed. It is now generally admitted that heartwood formation is a developmentally controlled process, functioning as a regulator of the amount of sapwood in the trunk [8,9]. During the conversion of sapwood into heartwood, extensive translocation of chemical compounds occurs. Secondary compounds tend to accumulate in heartwood, while storage products (starch), soluble sugars, amino-acids and mineral elements are removed from senescing sapwood rings $[9,10,15,16,32,50,76]$.

The assumption that heartwood has lower concentrations of all mineral nutrients compared to sapwood mostly derives from the widely cited papers by Bamber [8] and Lambert [38] both of which being based almost exclusively on Eucalypts. In the last 20 years, however, the emergence of dendrochemistry has yielded a large amount of new data on mineral element concentrations in heartwood and sapwood $[17,66]$. The picture emerging from these new data might be more complex than previously thought. In particular, higher concentrations of specific mineral elements in heartwood compared to sapwood have been reported [52, 63]. Furthermore, the difference in concentration between heartwood and sapwood may depend on element, species and life-form (Gymnosperms vs. Angiosperms) [13, 54, 56, 57], making generalisations difficult. Clearly, our knowledge of nutrient resorption from senescing wood lags far behind that of nutrient resorption from leaves [15, 25, 37]. Improved knowledge of mineral nutrient economy of trees is crucial to the understanding of the response of forest ecosystems to environmental stress [48].

In this paper, we explore patterns in macronutrient concentrations $(\mathrm{N}, \mathrm{P}, \mathrm{K}, \mathrm{Ca}, \mathrm{Mg}$ ) in heartwood and sapwood based on literature data. Our specific objectives are as follows: (i) to assess variation ranges and mean values of mineral nutrient concentrations in heartwood and sapwood; (ii) to test whether mineral nutrient concentrations are systematically lower in heartwood compared to sapwood; (iii) to test whether the heartwood/sapwood concentration ratio varies depending on element; (iv) to test whether Gymnosperms and Angiosperms have contrasting patterns and (v) to investigate correlations among different elements.

In the discussion it is examined whether the results are consistent with the hypothesis that mineral nutrients are resorbed from senescing wood.

\section{MATERIALS AND METHODS}

The database consists of literature values of macronutrient concentrations ( $\mathrm{N}, \mathrm{P}, \mathrm{K}, \mathrm{Ca}, \mathrm{Mg})$ in the heartwood and the sapwood of a total of 93 tree species (22 Gymnosperms and 71 Angiosperms). The data were compiled from papers published between 1957 and 1999 (Appendix). The data set is unbalanced, with the number of observations for $\mathrm{N}, \mathrm{P}, \mathrm{K}, \mathrm{Ca}$ and $\mathrm{Mg}$ being 56, 64, 80, 92 and 76, respectively. The original data were reported either as average sapwood and heartwood concentration or as radial concentration profiles. In the latter case, data were extracted as follows. For heartwood concentrations, the median value was used, except in a few cases where there existed a steep, outwardly decreasing concentration gradient in the heartwood, followed by a sharp concentration increase at the heartwood/sapwood boundary. In such cases, sapwood should be compared with the outermost heartwood ring to obtain a reliable picture of translocation processes that may be occurring at the heartwood-sapwood transition zone [5]. Sapwood concentrations were median values, except when outwardly increasing concentration gradients existed within the sapwood. In these cases, the outermost ring group or the penultimate annual growth ring was used; the outermost ring was discarded, due to possible contamination by the mineral-rich bark and cambium. When the original paper reported concentrations from several individuals, sites or trunk heights, the oldest individual was retained and the data were taken from $1.3 \mathrm{~m}$ (or the nearest height sampled); cross-sites averages were computed as necessary. Dendroanalytical studies explicitly aimed to monitor environmental pollution were not retained, except when an unpolluted site was included as a control. Data not expressed in concentration units per unit wood mass were not included. In some cases, data had to be tabulated from figures, and this was performed with the best possible approximation. In the case of the large data set of Lambert [38] on 38 species of Eucalyptus, a subsample of six species was included (the first two species in alphabetic order in each of the three subgenera Corymbia, Monocalyptus and Symphyomyrtus), using the sites for which nitrogen concentrations were reported. The four other species of Eucalyptus included in the data set are from [10].

The data were statistically analysed with SYSTAT. Cross-species means, standard deviations, minimum and maximum values for sapwood and heartwood concentrations were calculated separately for Gymnosperms and Angiosperms and for both groups pooled. Concentration ratios of mineral nutrients in heartwood and sapwood were calculated. The values were compared between Angiosperms and Gymnosperms by means of Mann-Whitney U-test. For each element, sapwood and heartwood concentrations were compared by means of Wilcoxon signed rank test. Correlations between heartwood/sapwood concentration ratios of different elements were assessed by means of Spearman rank correlation coefficient. An allometric approach was applied to analyse correlation patterns between heartwood and sapwood concentrations of each element. To that end, the allometric regression line of heartwood vs. sapwood concentration was calculated as the reduced major axis of the bi-plot of log-transformed values of heartwood $(\mathrm{Y})$ and sapwood $(\mathrm{X})$ concentrations. The allometric model used was $\mathrm{Y}=\mathrm{b} \mathrm{X}^{\mathrm{a}}$. In this model, an allometric coefficient (a) equal to unity indicates that heartwood and sapwood concentrations vary in a 1:1 ratio or, in other words, that the heartwood/sapwood concentration ratio does not vary systematically with sapwood concentration. a $<1$ indicates that heartwood concentration increases less rapidly than sapwood concentrations, or, in other words, that the heartwood/sapwood concentration ratio decreases with increasing sapwood concentrations. Finally, a $>1$ points to an increase in heartwood/sapwood concentration ratio with increasing sapwood concentration. Conformity tests for allometric coefficients were performed after [18].

\section{RESULTS}

Heartwood concentrations were lower than sapwood concentrations in 42 of 56 cases for $\mathrm{N}$ (Wilcoxon signed rank test: $\mathrm{Z}=4.61, P<0.001)$, in 59 of 64 cases for $\mathrm{P}(\mathrm{Z}=5.59, P<0.001)$, 
Table I. Mineral element concentrations in heartwood and sapwood and heartwood/sapwood concentration ratio: mean values \pm standard deviation for Angiosperms and Gymnosperms.

\begin{tabular}{lcccc}
\hline & $\mathrm{n}$ & $\begin{array}{c}\text { Heartwood } \\
\% \text { dry matter }\end{array}$ & $\begin{array}{c}\text { Sapwood } \\
\% \text { dry matter }\end{array}$ & $\begin{array}{c}\text { Heartwood/sapwood } \\
\text { concentration ratio }\end{array}$ \\
\hline \multicolumn{2}{l}{ Angiosperms } & & & \\
$\mathrm{N}$ & 47 & $0.117 \pm 0.050$ & $0.174 \pm 0.078$ & $0.76 \pm 0.42$ \\
$\mathrm{P}$ & 50 & $0.005 \pm 0.012$ & $0.013 \pm 0.011$ & $0.38 \pm 0.43$ \\
$\mathrm{~K}$ & 59 & $0.087 \pm 0.088$ & $0.127 \pm 0.062$ & $0.69 \pm 0.70$ \\
$\mathrm{Ca}$ & 66 & $0.154 \pm 0.200$ & $0.157 \pm 0.236$ & $1.33 \pm 1.43$ \\
$\mathrm{Mg}$ & 51 & $0.037 \pm 0.058$ & $0.032 \pm 0.028$ & $1.03 \pm 1.07$ \\
$\mathrm{Gymnosperms}$ & & & \\
$\mathrm{N}$ & 9 & $0.080 \pm 0.050$ & $0.103 \pm 0.042$ & $0.77 \pm 0.26$ \\
$\mathrm{P}$ & 14 & $0.002 \pm 0.002$ & $0.009 \pm 0.007$ & $0.28 \pm 0.28$ \\
$\mathrm{~K}$ & 21 & $0.080 \pm 0.120$ & $0.077 \pm 0.059$ & $1.05 \pm 1.11$ \\
$\mathrm{Ca}$ & 26 & $0.097 \pm 0.101$ & $0.090 \pm 0.070$ & $1.05 \pm 0.40$ \\
$\mathrm{Mg}$ & 25 & $0.019 \pm 0.012$ & $0.014 \pm 0.009$ & $1.54 \pm 1.14$ \\
\hline
\end{tabular}

in 60 of 80 cases for $\mathrm{K}(\mathrm{Z}=4.13, P<0.001)$, in 49 of 92 cases for $\mathrm{Ca}(\mathrm{Z}=0.14, \mathrm{~ns})$ and in 38 of 76 cases for $\mathrm{Mg}(\mathrm{Z}=0.98$, ns) (Appendix). These results were not qualitatively different between Gymnosperms and Angiosperms, even though the proportion of observations with lower concentrations in heartwood compared to sapwood is lower in Gymnosperms in the case of $\mathrm{Ca}$ ( 11 of 26 cases in Gymnosperms; 38 of 66 cases in Angiosperms) and Mg (8 of 23 cases in Gymnosperms; 30 of 53 cases in Angiosperms).

Compared to Gymnosperms (G), Angiosperms (A) had higher concentrations of all elements in the sapwood (table I). The difference was significant for N (A: $0.174 \%$, G: $0.103 \%$, Mann-Whitney U-test $=83.5, P<0.01), \mathrm{K}$ (A: $0.127 \%, \mathrm{G}: 0.077 \%, \mathrm{U}=220.5, P<0.001$ ) and $\mathrm{Mg}$ (A: $0.032 \%$, G: $0.014 \%, \mathrm{U}=258, P<0.001$ ). Heartwood concentrations were also higher in Angiosperms compared to Gymnosperms for all elements, but the difference was significant for $\mathrm{N}$ only (A: $0.117 \%, \mathrm{G}: 0.080 \%, \mathrm{U}=110, P<0.05$ ).

Nutrient concentrations in heartwood span two (N) to three (all other elements) orders of magnitude across species. The lowest absolute concentrations in heartwood decreased in the following order: $\mathrm{N}(\mathrm{A}: 0.038 \% ; \mathrm{G}: 0.040 \%)>\mathrm{Ca}$ (A: $0.003 \%$, G: $0.020 \%)>\mathrm{Mg}(\mathrm{A}: 0 \%, \mathrm{G}: 0.004 \%)>\mathrm{K}$ (A: $0.001 \%, \mathrm{G}: 0 \%)>\mathrm{P}(\mathrm{A}: 0.00 \%, \mathrm{G}: 0.00 \%)$.

Heartwood/sapwood concentration ratios increased in the following order: $\mathrm{P}(0.36)<\mathrm{N}(0.76)<\mathrm{K}(0.78)<\mathrm{Mg}(1.20)=$ $\mathrm{Ca}$ (1.25) (Angiosperms and Gymnosperms pooled) (table I); all pairwise comparisons between elements were significant except between $\mathrm{Ca}$ and $\mathrm{Mg}$. There was no significant difference between Angiosperms and Gymnosperms in the heartwood/sapwood concentration ratio except for $\mathrm{Mg}$ (A: 1.03, $\mathrm{G}: 1.54, \mathrm{U}=389, P<0.01)$. Thus, on average, $\mathrm{Mg}$ was more markedly accumulated in the heartwood in Gymnosperms.
Table II. Spearman rank correlation coefficients between heartwood/sapwood concentration ratio of different elements. $* P<0.05$; *** $P<0.001$.

\begin{tabular}{lllll}
\hline & $\mathrm{N}$ & $\mathrm{P}$ & $\mathrm{K}$ & $\mathrm{Ca}$ \\
\hline $\mathrm{P}$ & $0.566(34) * * *$ & & & \\
$\mathrm{~K}$ & $0.390(35) *$ & $0.414(63) * * *$ & & \\
$\mathrm{Ca}$ & $0.246(35)$ & $0.204(65)$ & $0.201(79)$ & \\
$\mathrm{Mg}$ & $0.264(34)$ & $0.341(50) *$ & $0.508(65) * * *$ & $0.568(75) * * *$ \\
\hline
\end{tabular}

Table III. Allometric relationships between heartwood and sapwood concentrations for five elements. $\mathrm{Y}=\mathrm{b} \mathrm{X}^{\mathrm{a}}$ or $\log \mathrm{Y}=\mathrm{b}+\mathrm{a} \log \mathrm{X}$, where $\mathrm{Y}=$ heartwood concentration; $\mathrm{X}=$ sapwood concentration; a $>1$ indicates that heartwood concentration increases more rapidly than sapwood concentration, i.e. increasing heartwood/sapwood concentration ratio with increasing sapwood concentration; conformity test of the allometric coefficient $\left(\mathrm{H}_{0}: \mathrm{a}=1\right)$. NS $P>0.05$; ** $P<0.01$; *** $P<0.001$

\begin{tabular}{lllll}
\hline & $\mathrm{n}$ & $\mathrm{r}^{2}$ & $\mathrm{a}$ & $\mathrm{t}$ \\
\hline $\mathrm{N}$ & 56 & 0.247 & 1.07 & $0.62 \mathrm{NS}$ \\
$\mathrm{P}$ & 64 & 0.197 & 1.75 & $6.60 * * *$ \\
$\mathrm{~K}$ & 80 & 0.284 & 2.44 & $12.52 * * *$ \\
$\mathrm{Ca}$ & 92 & 0.554 & 1.19 & $3.72 * *$ \\
$\mathrm{Mg}$ & 76 & 0.339 & 1.75 & $7.67 * * *$ \\
\hline
\end{tabular}

There were significant, positive correlations between heartwood/sapwood concentration ratios for four element pairs, namely $\mathrm{N}$ and $\mathrm{P}, \mathrm{P}$ and $\mathrm{K}, \mathrm{K}$ and $\mathrm{Mg}, \mathrm{Ca}$ and $\mathrm{Mg}$; the other pairwise correlations were all positive, but not significantly so (table II).

Cross-species correlations between concentration in sapwood and heartwood were highly significant for all elements (table III; figure 1). The slope of the heartwood-sapwood allometric regression line was superior to unity for all elements, significantly so for $\mathrm{P}, \mathrm{K}, \mathrm{Ca}$ and $\mathrm{Mg}$ (table III). Thus, for these elements, concentrations vary within narrower limits in sapwood than in heartwood or, in other words, species with low concentrations in sapwood tend to have disproportionately lower concentrations in heartwood.

\section{DISCUSSION}

\subsection{Do the results fit in with a scenario of mineral element resorption from senescing wood?}

Much attention has been paid to foliar nutrient resorption as a mechanism increasing mean residence time of nutrients within the plant, a component of nutrient use efficiency [2, $3,25,36,37,55,65]$. The similarity, from a functional point of view, between heartwood formation and leaf senescence has often been postulated $[7,9,37-39,71,72,74]$. Since the pioneering works of Merrill and Cowling [50] and Ziegler 

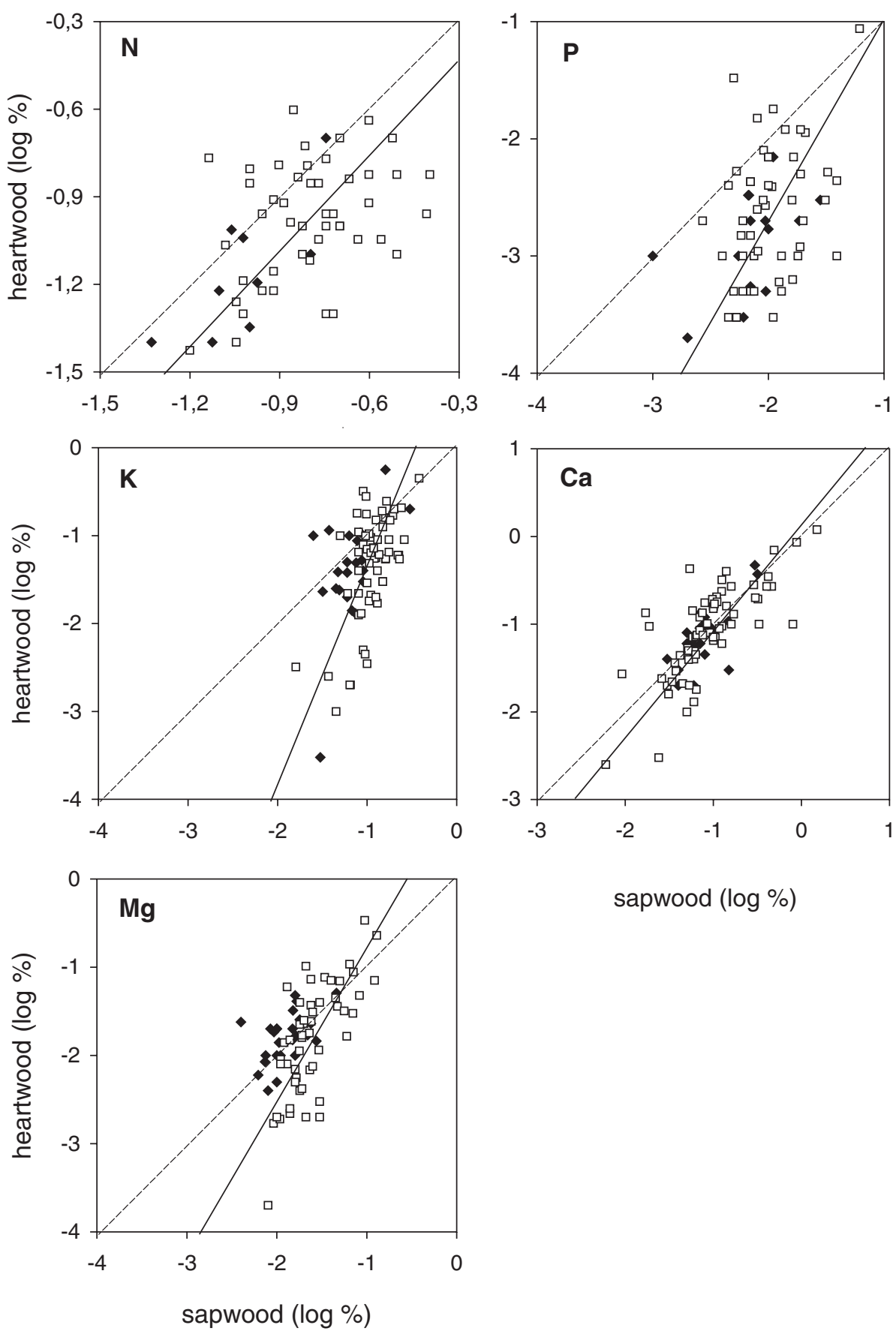

sapwood (log \%)

Figure 1. Allometric regression lines between heartwood and sapwood concentrations of N, P, K, Ca and Mg. $\square$ Angiosperms, $\bullet$ Gymnosperms; the stippled line denotes equal concentration in sapwood and heartwood.

[76], it is generally assumed that $\mathrm{N}$ - and P-compounds are actively hydrolysed and retrieved from senescing sapwood rings. However, the observation of differences in mineral nutrient concentrations between heartwood and sapwood does not in itself prove that translocations are involved. First, wood structure and chemical composition change with cambial age $[12,33,60]$. For instance, wood cation binding capacity generally decreases from pith to cambium [11,52]. Secondly, accumulation of secondary metabolites and formation of tyloses might alter mineral element concentrations at the time of heartwood formation, without any translocation of mineral elements being involved. Fungal infection can also alter the mineral element content of heartwood [59]. 
In a recent review of nutrient conservation strategies in plants Eckstein et al. [25] stated that "There is probably no resorption from woody stems [...]". The skepticism surrounding this issue may be rooted in the fact that "Information about movements of water and mineral nutrients in rays is mostly derived from indirect evidence" [77]. Admittedly, comparing average nutrient concentrations in sapwood and heartwood at a single height in trunk does not allow to discuss the complex dynamics of mineral nutrient translocations in woody stems $[15,16]$. Another limitation of the database is that nutrient content (i.e. concentrations weighed by the biomass of sapwood and heartwood) is not available. In the very few studies that have carefully examined the dynamics of mineral element translocations in woody stems, ColinBelgrand et al. $[15,16]$ have convincingly demonstrated that mineral nutrients are indeed removed from senescing sapwood, although a substantial proportion of mineral nutrient fluxes may actually occur in the vertical direction.

In spite of the abovementioned limitations, our results appear to be consistent with the hypothesis that specific mineral nutrients are removed from senescing sapwood. First, heartwood/sapwood concentration ratio was highly element-specific. This result would be difficult to explain by a "dilution effect" through accumulation of secondary metabolites in the heartwood. Secondly, the differences among elements and the correlation pattern among them (N-P on the one hand and $\mathrm{Ca}-\mathrm{Mg}$ on the other hand) are consistent with the well-known differences in mobility and chemical form of these elements in the xylem. Thus, a high proportion of $\mathrm{N}, \mathrm{P}$ and $\mathrm{K}$ is located in the symplast of parenchyma ray cells $[50,64,72]$ which is thought to be withdrawn during sapwood senescence $[27,66$, 76]. In contrast, a substantial proportion of $\mathrm{Ca}$ and $\mathrm{Mg}$ in wood is located in the cell wall either adsorbed on negatively charged exchange sites or incorporated in the form of pectates or in the lignin matrix $[17,44,48]$. $\mathrm{Ca}$ and $\mathrm{Mg}$ are thus less mobile than $\mathrm{N}, \mathrm{P}$ and $\mathrm{K}$ in the xylem [17, 44]. It is worth noticing, however, that specific genera (e.g. Eucalyptus and Quercus) consistently exhibit lower concentrations of $\mathrm{Ca}$ and $\mathrm{Mg}$ in the heartwood compared to the sapwood, suggesting that resorption of these elements is not physiologically impossible.

\subsection{Lower concentrations of $N, P$ and $K$ in the heartwood}

Heartwood generally has lower concentrations of $\mathrm{P}, \mathrm{N}$ and K compared to sapwood $(92 \%, 75 \%$ and $75 \%$ of records, respectively). The few outliers for $\mathrm{P}$ and $\mathrm{N}$ are mostly from a single study concerning a mountain rainforest in New Guinea [28], and it is possible that the corresponding trees did not possess typical heartwood. Lambert \& Turner [39] suggest that tropical rainforest trees might be less efficient at resorbing nutrients from senescing wood, this being compensated for by a more efficient foliar resorption. This hypothe- sis cannot be validly tested here due to the limited number of data for tropical species.

In leaves, the intensity of elemental transfers during senescence usually decreases in the following order: $\mathrm{N} \approx \mathrm{P}>\mathrm{K}>$ $\mathrm{Mg}>\mathrm{Ca}[45,66]$. The similarities in the pattern of nutrient resorption from leaves and from wood are striking, considering the vast differences in chemical composition of wood and leaf tissues.

Heartwood/sapwood concentration ratio was markedly lower for $\mathrm{P}$ compared to $\mathrm{N}\left(\mathrm{N}: 0.76, \mathrm{P}: 0.36, \mathrm{t}^{118}=5.43\right.$, $P<0.001)$. This ratio was lower for $\mathrm{P}$ than for $\mathrm{N}$ in 27 of 33 studies where both elements were analysed (Appendix). These findings are surprising, considering that $\mathrm{N}$ and $\mathrm{P}$ have similar average foliar resorption efficiency (ca. 50\%) [3]. $\mathrm{P}$ may thus be the main target of resorption from senescing wood. In line with these results, $\mathrm{P}$ in sapwood is in the form of adenine nucleotides which are massively translocated during conversion to heartwood [42]. Analytical difficulties may be suspected in a few cases, where extremely low P concentrations were reported in heartwood.

\subsection{Complex patterns of divalent cations}

Compared to $\mathrm{N}$ and $\mathrm{P}$, the pattern of $\mathrm{Ca}$ and $\mathrm{Mg}$ is much more variable among species, ranging from markedly lower concentrations in heartwood to accumulation into heartwood, with a majority of species showing similar concentrations in either tissue. In specific cases, higher concentration of $\mathrm{Ca}$ in heartwood reflects accumulation of this element in the form of crystals [32-34]. In contrast, all species of Quercus and Eucalyptus in the database had markedly lower concentrations of $\mathrm{Ca}$ and $\mathrm{Mg}$ in heartwood compared to sapwood, suggesting that the radial distribution pattern of these elements in wood is subject to strong phylogenetic constraints.

Okada et al. [56, 57] stated that Gymnosperms generally had outwardly decreasing concentrations of cations in stemwood, while Angiosperms would not show the same trend. Our results reveal a rather more complex pattern, with large variation within both groups. In Gymnosperms, the outwardly decreasing profile seems to hold true for $\mathrm{Mg}$ only. Outwardly decreasing concentrations of alkaline earth elements in coniferous stemwood have been ascribed to decreasing wood cation binding capacity $(\mathrm{CBC})$ from pith to bark, possibly due to a similar decrease in the proportion of pectic materials [11, 49, 52]. CBC might also increase with wood ageing and $\mathrm{Mg}$ would then migrate centripetally and adsorb on the acquired binding sites $[11,52]$. The lower mobility of $\mathrm{Ca}$ in xylem might explain why this element is less markedly accumulated in heartwood in Gymnosperms.

Phylogenetic constraints on cation distribution patterns in wood are not that strong, since one of the most striking cases of $\mathrm{Ca}$ and $\mathrm{Mg}$ resorption from senescing wood was documented in the Gymnosperm Chamaecyparis thyoides [4, 5]. In this species, both $\mathrm{Ca}$ and $\mathrm{Mg}$ have outwardly decreasing 
concentrations in the heartwood, followed by a sharp concentration increase in the sapwood. A comprehensive interpretation of cation distribution patterns in stemwood will not be possible until extensive measurements of radial variation of wood $\mathrm{CBC}$ become available.

\subsection{Are there differences between Gymnosperms and Angiosperms?}

Gymnosperms apparently have lower concentrations of all mineral nutrients in the sapwood compared to Angiosperms, although the limited number of data (especially for $\mathrm{N}$ and $\mathrm{P}$ in Gymnosperm sapwood) precludes from drawing definitive conclusions. This result could be due to a direct environmental effect, since evergreen coniferous species often occupy nutrient-poorer sites than broad-leaved, deciduous trees [1, $37,65]$. In line with our results, lower wood concentrations of $\mathrm{N}$ and $\mathrm{K}$ for Gymnosperms compared to Angiosperms have already been reported (e.g. [70]). The lower mineral element concentrations in Gymnosperm sapwood may well be constitutive, since $\mathrm{N}$ concentration in wood is correlated to the proportion of living parenchyma cells [50], which is lower in Gymnosperm sapwood compared to Angiosperms [32]. It is well known that evergreen species, including Conifers, have intrinsically lower concentrations of $\mathrm{N}$ in leaves (on a mass basis) compared to deciduous species and such low foliar concentrations are regarded as a key component of the nutrient conservation strategy of evergreens [1-3,37]. Our results suggest that, for Conifers, this conclusion could be extended to wood.

\subsection{Heartwood-sapwood correlation}

The positive correlation between sapwood and heartwood concentrations for all elements is a striking pattern emerging from this study. In this respect, wood resorption is similar to foliar resorption, because species with nutrient-rich leaves also tend to have higher nutrient concentrations in senesced leaves $[2,65]$.

The slope of the heartwood/sapwood allometric regression line was significantly superior to 1 for all elements except N. In other words, species with nutrient-poor sapwood tend to have disproportionately poorer heartwood. Assuming that sapwood mineral element concentrations reflect the tree's nutritional status [22] this result might point to a nutritional control on wood resorption. However, this control is relatively weak since there exist species with nutrient-rich sapwood which have low heartwood/sapwood concentration and vice versa. The possibility that nutrient resorption efficiency is enhanced in conditions of low nutrient availability has received much attention, because it might represent an adaptation to nutrient-poor habitats [1-3]. This hypothesis has been rarely tested for wood. In Chamaecyparis thyoides, wood resorption of $\mathrm{K}, \mathrm{Ca}$ and $\mathrm{Mg}$ was more complete, i.e. heartwood concentrations were lower, in sites with lower availability of these elements in the soil, pointing to a direct environmental control on wood resorption [5]. In the present study, it is not possible to discriminate between species-specific differences and direct environmental effects, because different species were sampled from sites with different mineral element availability.

\section{CONCLUSIONS}

The distribution pattern of mineral element concentrations in sapwood and heartwood provides circumstantial support to the hypothesis that $\mathrm{N}, \mathrm{P}$ and $\mathrm{K}$ are generally translocated from senescing sapwood. In view of its low heartwood/sapwood concentration ratio, $\mathrm{P}$ would appear to be the main target of the resorption process in wood.

In contrast, large variation exists in the concentration patterns of divalent cations, whose functional significance needs further investigation, particularly in the broader context of alkaline earth depletion of forest soil through atmospheric pollution. Extensive measurements of radial profiles of cation binding capacity of wood are required to address this interesting issue.

Gymnosperms have lower concentrations of mineral nutrients in the wood compared to Angiosperms, a feature which may contribute to their higher nutrient use efficiency.

Future work should be directed to investigating the functional relationships between foliar and wood resorption, in relation to life form (evergreen vs. deciduous), taxonomic group (Gymnosperms vs. Angiosperms) and climate (tropical vs. non tropical) and to testing the hypothesis of a nutritional control on mineral nutrient resorption from senescing wood.

Acknowledgements: This work benefited from stimulating discussions with Jacques Herbauts and Valérie Penninckx.

\section{REFERENCES}

[1] Aerts R., The advantages of being evergreen, Trends Ecol. Evol. 10 (1995) 402-406.

[2] Aerts R., Nutrient resorption from senescing leaves of perennials: are there general patterns?, J. Ecol. 84 (1996) 597-608.

[3] Aerts R., Chapin F.S.III, The mineral nutrition of wild plants revisited: a re-evaluation of processes and patterns, Adv. Ecol. Res. 30 (2000) 1-67.

[4] Andrews J.A., Siccama T.G., Retranslocation of calcium and magnesium at the heartwood-sapwood boundary in Atlantic white cedar, Ecology 76 (1995) 659-663.

[5] Andrews J.A., Siccama T.G., Vogt K.A., The effect of soil nutrient availability on retranslocation of $\mathrm{Ca}, \mathrm{Mg}$ and $\mathrm{K}$ from senescing sapwood in Atlantic white cedar, Plant Soil 208 (1999) 117-123.

[6] Attiwill P.M., Nutrient cycling in a Eucalyptus obliqua (L'Hérit.) forest. IV. Nutrient uptake and nutrient return, Aust. J. Bot. 28 (1980) 199-222.

[7] Augusto L., Ranger J., Ponette Q., Rapp M., Relationships between forest tree species, stand production and stand nutrient amount, Ann. For. Sci. 57 (2000) 313-324.

[8] Bamber R.K., Heartwood, its function and formation, Wood Sci. Technol. 10 (1976) 1-8. 
[9] Bamber R.K., Fukazawa K., Sapwood and heartwood: a review, Forestry Abst. 46 (1985) 567-580.

[10] Beadle N.C.W., White G.J., The mineral content of the trunks of some Australian woody plants, Proc. Ecol. Soc. Aust. 3 (1968) 55-60.

[11] Bondietti E.A., Momoshima N., Shortle W.C., Smith K.T., A historical perspective on divalent cation trends in red spruce stemwood and the hypothetical relationship to acidic deposition, Can. J. For. Res. 20 (1990) $1850-1858$

[12] Braun H.P., Funktionelle Histologie der sekundären Sprossachse. I. Das Holz, Borntraeger, Berlin, 1970.

[13] Chun L., Hui-Yi H., Tree-ring element analysis of Korean pine (Pinus koraiensis Sieb. et Zucc.) and Mongolian oak (Quercus mongolica Fisch. ex Turcz.) from Changai Mountain, north-east China, Trees 6 (1992) 103-108.

[14] Clément A., Janin G., Étude comparée de la répartition des principaux cations et du phosphore dans une tige de peuplier "Fritzi-Pauley", Plant Soil 45 (1976) 543-554.

[15] Colin-Belgrand M., Ranger J., Bouchon J., Internal translocation in chestnut tree stemwood: III. Dynamics across an age series of Castanea sativa Miller, Ann. Bot. 78 (1996) 729-740.

[16] Colin-Belgrand M., Ranger J., d'Argouges S., Transferts internes d'éléments nutritifs dans le bois de châtaignier (Castanea sativa Miller) : approche dynamique sur une chronoséquence de peuplements. I. Distribution des éléments minéraux, Acta Oecol. 14 (1993) 653-680.

[17] Cutter B.E., Guyette R.P., Anatomical, chemical and ecological factors affecting tree species choice in dendrochemistry studies, J. Environ. Qual. 22 (1993) 611-619.

[18] Dagnelie P., Théorie et méthodes statistiques. II, Les Presses agronomiques de Gembloux, Gembloux, 1975.

[19] Dambrine E., Le Goaster S., Ranger J., Croissance et nutrition minérale d'un peuplement d'épicéa sur sol pauvre. III. Prélèvement racinaire et translocation d'éléments minéraux au cours de la croissance, Acta Oecol. 12 (1991) 791-808.

[20] Denaeyer-De Smet S., Teneurs en éléments biogènes des tapis végétaux dans les forêts caducifoliées d'Europe, in: Duvigneaud P. (Ed.), Productivité des écosystèmes forestiers, Actes du Colloque de Bruxelles, Unesco, Paris, 1971, pp. 515-525.

[21] De Visser P.H.B., The relations between chemical composition of oak tree rings, leaf, bark and soil solution in a partly mixed stand, Can. J. For. Res. 22 (1992) 1824-1831.

[22] DeWalle D.R., Swistock B.R., Sayre R.G., Sharpe W.E., Spatial variations of sapwood chemistry with soil acidity in Appalachian forests, J. Environ. Qual. 20 (1991) 486-491.

[23] Duvigneaud P., Denaeyer-De Smet S., Biomass, productivity and mineral cycling in mixed forests in Belgium, in: Young H.E. (Ed.), Symposium on primary productivity and mineral cycling in natural ecosystems, University of Maine Press, Orono, 1968, pp. 167-186.

[24] Duvigneaud P., Denaeyer-De Smet S., Biological cycling of minerals in temperate deciduous forests, in: Reichle D.E. (Ed.), Ecological studies 1, Springer-Verlag, Berlin, 1970, pp. 199-225.

[25] Eckstein R.L., Karlsson P.S., Weih M., Leaf life span and nutrient resorption as determinants of plant nutrient conservation in temperate-arctic regions, New Phytol. 143 (1999) 177-190.

[26] Fiedler H.-J., Höhne H., Vorkommen und Gehalt der Makronährstoffe in Wald baümen, Wiss. Zeits. Techn. Univ. Dresden 14 (1965) 989-999.

[27] Frey-Wyssling A., Bosshard H.H., Cytology of the ray-cells in sapwood and heartwood, Holzforsch. 13 (1959) 129-137.

[28] Grubb P.J., Edwards P.J., Studies of mineral cycling in a montane rain forest in New Guinea. III. The distribution of mineral elements in the above ground material, J. Ecol. 70 (1982) 623-648.

[29] Hart J.H., Morphological and chemical differences between sapwood, discoloured sapwood and heartwood in black locust and osage orange, For. Sci. 14 (1968) 334-338.

[30] Häsänen E., Huttunen S., Acid deposition and the element composition of pine tree rings, Chemosphere 18 (1989) 1913-1920.
[31] Helmisaari H.-S., Siltala T., Variation in nutrient concentrations of Pinus sylvestris stems, Scand. J. For. Res. 4 (1989) 443-451. 1987

[32] Hillis W.E., Heartwood and tree exudates, Springer-Verlag, Berlin,

[33] Jane F.W., The structure of wood, Adam and Charles Black, London, 1954.

[34] Janin G., Clément A., Mise en évidence de cristaux de carbonate de calcium dans le bois des peupliers. Conséquences sur la répartition des ions minéraux liée à la duraminisation, Ann. Sci. For. 29 (1972) 67-105.

[35] Kashuba-Ockenberry L.A., De Walle D.R., Dendrochemical response to soil liming in scarlet oak, Can. J. For. Res. 24 (1994) 564-567.

[36] Killingbeck K.T., Nutrients in senesced leaves: keys to the search for potential resorption and resorption proficiency, Ecology 77 (1996) 1716-1727.

[37] Lambers H., Chapin F.S.III, Pons T.L., Plant Physiological Ecology, Springer-Verlag, Berlin, 1998.

[38] Lambert M.J., Inorganic constituents in wood and bark of New South Wales forest tree species, Forestry Commiss. New South Wales, Research Note 45 (1981) 1-43.

[39] Lambert M.J., Turner J., Redistribution of nutrients in subtropical rainforest trees, Proc. Linn. Soc. New South Wales 111 (1989) 1-10.

[40] Lévy G., Bréchet C., Becker M., Element analysis of tree rings in pedunculate oak heartwood: an indicator of historical trends in the soil chemistry, related to atmospheric deposition, Ann. Sci. For. 53 (1996) 685-696.

[41] Long R.P., Davis D.D., Major and trace element concentrations in surface organic layers, mineral soil, and white oak xylem downwind from a coal-fired power plant, Can. J. For. Res. 19 (1989) 1603-1615.

[42] Magel E.A., Höll W., Storage carbohydrates and adenine nucleotides in trunks of Fagus sylvatica L. in relation to discoloured wood, Holzforschung 47 (1993) 19-24.

[43] Majumdar S.K., Halma J.R., Cline S.W., Rieker D., Daehler C., Zelnick R.W., Saylor T., Geist S., Tree ring growth and elemental concentrations in wood cores of oak species in Eastern Pennsylvania: possible influences of air pollution and acidic deposition, Environ. Technol. 12 (1991) 41-49.

[44] Marschner H., Mineral nutrition of higher plants, Academic Press Inc., San Diego CA, 1995.

[45] Martin J.G., Kloeppel B.D., Schaefer T.L., Kimbler D.L., McNulty S.G., Aboveground biomass and nitrogen allocation of ten deciduous southern Appalachian tree species, Can. J. For. Res. 28 (1998) 1648-1659.

[46] Masson G., Cabanis M.T., Cabanis J.C., Puech J.-L., The amounts of inorganic elements in cooperage oak, Holzforschung 51 (1997) 497-502.

[47] Matusiewicz H., Barnes R.M., Tree ring wood analysis after hydrogen peroxide pressure decomposition with inductively coupled plasma atomic emission spectrometry and electrothermal vaporization, Anal. Chem. 57 (1985) 406-411.

[48] McLaughlin S.B., Wimmer R., Calcium physiology and terrestrial ecosystem processes, New Phytol. 142 (1999) 373-417.

[49] McMillin C.W., Mineral content of loblolly pine wood as related to specific gravity, growth rate and distance from pith, Holzforschung 24 (1970) $152-157$.

[50] Merrill W., Cowling E.B., Role of nitrogen in wood deterioration: amounts and distribution in tree stems, Can. J. Bot. 44 (1966) 1555-1580.

[51] Miller R.B., Plant nutrients in hard beech. I. The immobilisation of nutrients, N. Z. J. Sci. 6 (1963) 365-377.

[52] Momoshima N., Bondietti E.A., Cation binding in wood: applications to understanding historical changes in divalent cation availability to red spruce, Can. J. For. Res. 20 (1990) 1840-1849.

[53] Momoshima N., Eto I., Kofuji H., Takashima Y., Koike M., Imaizumi Y., Harada T., Distribution and chemical characteristics of cations in annual rings of Japanese Cedar, J. Envir. Qual. 24 (1995) 1141-1149.

[54] Myre R., Camiré C., Distribution de P, K, Ca, Mn et Mg dans la tige des mélèzes européen et laricin, Ann. Sci. For. 51 (1994) 121-134.

[55] Nambiar E.K.S., Fife D.N., Nutrient retranslocation in temperate conifers, Tree Physiol. 9 (1991) 185-207. 
[56] Okada N., Katayama Y., Nobuchi T., Ishimaru Y., Aoki A., Trace elements in the stems of trees. V. Comparison of radial distributions among softwood stems, Mokuzai Gakkaishi 39 (1993) 111-118.

[57] Okada N., Katayama Y., Nobuchi T., Ishimaru Y., Aoki A., Trace elements in the stems of trees. VI. Comparisons of radial distributions among hardwood stems, Mokuzai Gakkaishi 39 (1993) 1119-1127.

[58] Oshima Y., Primary Production team, Primary production, in: Kitazawa Y. (Ed.), Ecosystem analysis of the subalpine coniferous forest of the Shigayama IBP area, central Japan, University of Tokyo Press, Tokyo, 1977, pp. 125-134.

[59] Ostrofsky A., Jellison J., Smith K.T., Shortle W.C., Changes in cation concentrations in red spruce wood decayed by brown rot and white rot fungi, Can. J. For. Res. 27 (1997) 567-571.

[60] Panshin A.J., De Zeeuw C., Braun H.P., Textbook of wood technology. I. Structure, identification, uses, and properties of the commercial woods of the United States, McGraw-Hill, New York, 1964.

[61] Penninckx V., Meerts P., Herbauts J., Gruber W., Ring width and element concentrations in beech (Fagus sylvatica $\mathrm{L}$.) from a periurban forest in central Belgium, For. Ecol. Manage. 113 (1999) 23-33.

[62] Ranger J., Étude de la minéralomasse et du cycle biologique dans deux peuplements de Pin laricio de Corse, dont l'un a été fertilisé à la plantation, Ann. Sci. For. 38 (1981) 127-158.

[63] Riitters K.H., Ohmann L.F., Grigal D.F., Woody tissue analysis using an element ratio technique (DRIS), Can. J. For. Res. 21 (1991) 1270-1277.

[64] Saka S., Mimori R., The distribution of inorganic constituents in white birch wood as determined by SEM-EDXA, Mokuzai Gakkaishi 40 (1994) 88-94.

[65] Schlesinger W.H., Biogeochemistry. An analysis of global change, Academic Press, San Diego, 1997.
[66] Smith K.T., Shortle W.C., Tree biology and dendrochemistry, in: Dean J.S., Meko D.M., Swetnam T.W. (Eds.), Tree rings, environment and humanity, Radiocarbon, 1996, pp. 629-635.

[67] Stewart C.M., Excretion and heartwood formation on living trees, Science 153 (1966) 1068-1074.

[68] Takashima Y., Koike M., Imaizumi Y., Harada T., Distribution and extraction behavior of elements in annual rings of Cryptomeria japonica and Abies firma, Bunseki Kagaku 43 (1994) 891-895.

[69] Taneda K., Ota M., Nagashima M., The radial distribution and concentration of several chemical elements in woods of five Japanese species, Mokuzai Gakkaishi 32 (1986) 833-841.

[70] Tsutsumi T., Kawahara T., Shidei T., The circulation of nutrients in forest ecosystem. I. On the amount of nutrients contained in the above-ground parts of single tree and of stand, J. Jap. For. Soc. 50 (1968) 66-74.

[71] Turner J., Lambert M.J., Nutrient cycling within a 27-year-old Eucalyptus grandis plantation in New South Wales, For. Ecol. Manage. 6 (1983) 155-168.

[72] Wardell J.F., Hart J.H., Radial gradients of elements in White Oak wood, Wood Sci. 5 (1973) 298-303.

[73] Watmough S.A., Hutchinson T.C., Sager E.P.S., Changes in tree ring chemistry in sugar maple (Acer saccharum) along an urban-rural gradient in southern Ontario, Environ. Pollut. 101 (1998) 381-390.

[74] Woodwell G.L., Whittaker R.H., Houghton R.A., Nutrient concentrations in plants in the Brookhaven oak-pine forest, Ecology 56 (1975) 318-332.

[75] Wright T.W., Will G.M., The nutrient content of Scots and Corsican pines growing on sand dunes, Forestry 30 (1957) 13-25.

[76] Ziegler H., Biologische Aspekte der Kernholzbildung, Holz Roh Werkst. 26 (1968) 61-68.

[77] Zimmermann M.H., Brown C.L., Trees, structure and function, Springer, Berlin, 1974. 
Appendix. Concentrations of N, P, K, Ca and Mg in the sapwood (s) and the heartwood (h), and heartwood/sapwood concentration ratio in Gymnosperms (taxon =1) and Angiosperms (taxon =2).

Concentrations in sapwood (s) and heartwood (h)

Heartwood/sapwood $\left(\mathrm{mg} \mathrm{kg}^{-1}\right)$

\begin{tabular}{|c|c|c|c|c|c|c|c|c|c|c|c|c|c|c|c|c|c|}
\hline Species & Taxon & $\mathrm{N}_{\mathrm{s}}$ & $\mathrm{N}_{\mathrm{h}}$ & $\mathrm{P}_{\mathrm{s}}$ & $\mathrm{P}_{\mathrm{h}}$ & $\mathrm{K}_{\mathrm{s}}$ & $\mathrm{K}_{\mathrm{h}}$ & $\mathrm{Ca}_{\mathrm{s}}$ & $\mathrm{Ca}_{\mathrm{h}}$ & $\mathrm{Mg}_{\mathrm{s}}$ & $\mathrm{Mg}_{\mathrm{h}}$ & $\mathrm{N}$ & $\mathrm{P}$ & $\mathrm{K}$ & $\mathrm{Ca}$ & $\mathrm{Mg}$ & Reference \\
\hline Abies firma & 1 & & & & & 3000 & 2000 & & & 110 & 100 & & & 0.67 & & 0.91 & {$[56]$} \\
\hline Abies firma & 1 & & & 20 & 2 & 250 & 1000 & 300 & 400 & 100 & 100 & & 0.10 & 4.00 & 1.33 & 1.00 & {$[68]$} \\
\hline Abies sacchalinensis & 1 & & & & & 630 & 1000 & 800 & 1200 & 150 & 200 & & & 1.59 & 1.50 & 1.33 & {$[56]$} \\
\hline Callitris columellaris & 1 & & & 10 & 10 & 320 & 230 & 3170 & 3710 & 460 & 510 & & 1.00 & 0.72 & 1.17 & 1.11 & {$[38]$} \\
\hline Callitris hugelii & 1 & & & 55 & 10 & 600 & 380 & 2960 & 4710 & 160 & 480 & & 0.18 & 0.63 & 1.59 & 3.00 & {$[38]$} \\
\hline Cedrus deodara & 1 & & & & & & & 1500 & 300 & & & & & & 0.20 & & {$[56]$} \\
\hline Chamaecyparis obtusa & 1 & & & & & 600 & 500 & 400 & 300 & 75 & 100 & & & 0.83 & 0.75 & 1.33 & {$[56]$} \\
\hline Chamaecyparis thyoides & 1 & & & & & & & 600 & 200 & 80 & 40 & & & & 0.33 & 0.50 & {$[5]$} \\
\hline Cryptomeria japonica & 1 & & & & & & & 606 & 562 & 93 & 184 & & & & 0.93 & 1.98 & [69] \\
\hline Cryptomeria japonica & 1 & & & & & 1600 & 5600 & 1000 & 800 & 100 & 200 & & & 3.50 & 0.80 & 2.00 & {$[56]$} \\
\hline Cryptomeria japonica & 1 & & & 70 & 5.5 & 375 & 1150 & 950 & 900 & 85 & 200 & & 0.08 & 3.07 & 0.95 & 2.35 & {$[53]$} \\
\hline Larix decidua & 1 & & & 280 & 30 & 678 & 140 & 709 & 600 & 164 & 167 & & 0.11 & 0.21 & 0.85 & 1.02 & {$[54]$} \\
\hline Larix laricina & 1 & & & 185 & 20 & 754 & 490 & 559 & 652 & 151 & 323 & & 0.11 & 0.65 & 1.17 & 2.14 & {$[54]$} \\
\hline Larix leptolepis & 1 & & & & & 600 & 200 & 400 & 200 & 100 & 50 & & & 0.33 & 0.50 & 0.50 & {$[56]$} \\
\hline Metasequoia glyptostroboides & 1 & & & & & & & 800 & 450 & 160 & 100 & & & & 0.56 & 0.63 & {$[56]$} \\
\hline Picea abies & 1 & 1600 & 800 & 95 & 5 & 900 & 300 & 600 & 700 & & & 0.50 & 0.05 & 0.33 & 1.17 & & [19] \\
\hline Picea rubens & 1 & & & & & 873 & 522 & 936 & 810 & 166 & 412 & & & 0.60 & 0.87 & 2.48 & {$[47]$} \\
\hline Picea rubens & 1 & & & & & & & 500 & 800 & 62 & 60 & & & & 1.60 & 0.97 & [11] \\
\hline Picea rubens & 1 & & & 67 & 33 & 776 & 875 & 597 & 673 & 74 & 85 & & 0.49 & 1.13 & 1.13 & 1.15 & {$[53]$} \\
\hline Pinus densiflora & 1 & & & & & 450 & 250 & 700 & 900 & 100 & 200 & & & 0.56 & 1.29 & 2.00 & {$[56]$} \\
\hline Pinus nigra & 1 & 950 & 910 & 94 & 20 & 900 & 400 & 570 & 660 & 180 & 255 & 0.96 & 0.21 & 0.44 & 1.16 & 1.42 & {$[75]$} \\
\hline Pinus rigida & 1 & 870 & 970 & 70 & 20 & 490 & 240 & 810 & 1040 & 275 & 146 & 1.11 & 0.29 & 0.49 & 1.28 & 0.53 & {$[74]$} \\
\hline Pinus strobus & 1 & 1000 & 450 & & & & & & & & & 0.45 & & & & & {$[50]$} \\
\hline Pinus sylvestris & 1 & 1060 & 640 & 100 & 17 & 740 & 130 & 580 & 710 & 240 & 230 & 0.60 & 0.17 & 0.18 & 1.22 & 0.96 & {$[75]$} \\
\hline Pinus sylvestris & 1 & 790 & 600 & 68 & 33 & 473 & 385 & 796 & 969 & 106 & 140 & 0.76 & 0.49 & 0.81 & 1.22 & 1.32 & {$[30]$} \\
\hline Pinus sylvestris & 1 & 470 & 400 & 61 & 3 & 300 & 3 & 500 & 600 & 150 & 150 & 0.85 & 0.05 & 0.01 & 1.20 & 1.00 & {$[31]$} \\
\hline Podocarpus archboldii & 1 & 1800 & 2000 & 110 & 70 & 840 & 1080 & 1480 & 1080 & 220 & 170 & 1.11 & 0.64 & 1.29 & 0.73 & 0.77 & {$[28]$} \\
\hline Thuyopsis dolobrata & 1 & & & & & & & 706 & 1330 & 40 & 239 & & & & 1.88 & 5.98 & [69] \\
\hline Tsuga diversifolia & 1 & 750 & 400 & & & & & & & & & 0.53 & & & & & {$[58]$} \\
\hline Acer rubrum & 2 & 900 & 400 & & & & & & & & & 0.44 & & & & & {$[45]$} \\
\hline Acer saccharum & 2 & & & & & 1260 & 1502 & 2874 & 2812 & 643 & 1084 & & & 1.19 & 0.98 & 1.69 & {$[47]$} \\
\hline Acer saccharum & 2 & & & 80 & 25 & & & 8000 & 1000 & & & & 0.31 & & 0.13 & & {$[73]$} \\
\hline Ackama paniculata & 2 & & & 53 & 53 & 1100 & 210 & 610 & 490 & & & & 1.00 & 0.19 & 0.80 & & {$[10]$} \\
\hline Aesculus turbinata & 2 & & & & & 500 & 1000 & 1250 & 3200 & 500 & 700 & & & 2.00 & 2.56 & 1.40 & {$[56]$} \\
\hline Ardisia sp. & 2 & 1250 & 1620 & 90 & 30 & 860 & 130 & 420 & 440 & 160 & 70 & 1.30 & 0.33 & 0.15 & 1.05 & 0.44 & {$[28]$} \\
\hline Banksia serratifolia & 2 & & & 58 & 15 & 1300 & 170 & 580 & 710 & & & & 0.26 & 0.13 & 1.22 & & {$[10]$} \\
\hline Betula lenta & 2 & 950 & 500 & & & & & & & & & 0.53 & & & & & {$[45]$} \\
\hline Carya sp. & 2 & 2500 & 1500 & & & & & & & & & 0.60 & & & & & {$[45]$} \\
\hline Castanea crenata & 2 & & & & & & & 366 & 363 & 210 & 20.1 & & & & 0.99 & 0.10 & {$[69]$} \\
\hline Castanea crenata & 2 & & & & & 1250 & 560 & 300 & 200 & 300 & 20 & & & 0.45 & 0.67 & 0.07 & {$[57]$} \\
\hline Castanea sativa & 2 & 1588 & 762 & 124 & 6 & 607 & 220 & 377 & 291 & 292 & 115 & 0.48 & 0.05 & 0.36 & 0.77 & 0.39 & {$[16]$} \\
\hline Casuarina cristata & 2 & & & 70 & 43 & 770 & 1800 & 8800 & 8600 & & & & 0.61 & 2.34 & 0.98 & & {$[10]$} \\
\hline Casuarina torulosa & 2 & & & 40 & 10 & 450 & 10 & 630 & 720 & 120 & 140 & & 0.25 & 0.02 & 1.14 & 1.17 & {$[38]$} \\
\hline Cedrela tonduzii & 2 & 1200 & 600 & & & & & & & & & 0.50 & & & & & {$[50]$} \\
\hline Ceiba pentendra & 2 & 3900 & 1100 & & & & & & & & & 0.28 & & & & & {$[50]$} \\
\hline Ceratopetalum apetalum & 2 & & & 209 & 113 & 1940 & 1695 & 187 & 944 & & & & 0.54 & 0.87 & 5.05 & & {$[10]$} \\
\hline Ceratopetalum apetalum & 2 & 1700 & 1400 & 45 & 40 & 800 & 1100 & 3210 & 1930 & 240 & 370 & 0.82 & 0.89 & 1.38 & 0.60 & 1.54 & {$[38]$} \\
\hline Cornus florida & 2 & 2000 & 2000 & & & & & & & & & 1.00 & & & & & {$[45]$} \\
\hline Cryptocarya sp. & 2 & 1000 & 1570 & 140 & 120 & 960 & 990 & 700 & 1200 & 950 & 3400 & 1.57 & 0.86 & 1.03 & 1.71 & 3.58 & {$[28]$} \\
\hline Dryadodaphne crassa & 2 & 1370 & 1030 & 60 & 10 & 2300 & 540 & 540 & 4300 & 1220 & 710 & 0.75 & 0.17 & 0.23 & 7.96 & 0.58 & {$[28]$} \\
\hline Elaeocarpus ptilanthus & 2 & 1200 & 1230 & 100 & 40 & 1180 & 720 & 1030 & 1700 & 210 & 1030 & 1.03 & 0.40 & 0.61 & 1.65 & 4.90 & {$[28]$} \\
\hline Eucalyptus cameronii & 2 & & & 53 & 3 & 370 & 25 & 240 & 30 & & & & 0.06 & 0.07 & 0.13 & & {$[10]$} \\
\hline Eucalyptus campanulata & 2 & & & 53 & 3 & 160 & 32 & 60 & 25 & & & & 0.06 & 0.20 & 0.42 & & {$[10]$} \\
\hline Eucalyptus dalrympleana & 2 & 2000 & 1000 & 615 & 870 & 2250 & 600 & 580 & 1430 & 470 & 360 & 0.50 & 1.41 & 0.27 & 2.47 & 0.77 & {$[38]$} \\
\hline
\end{tabular}




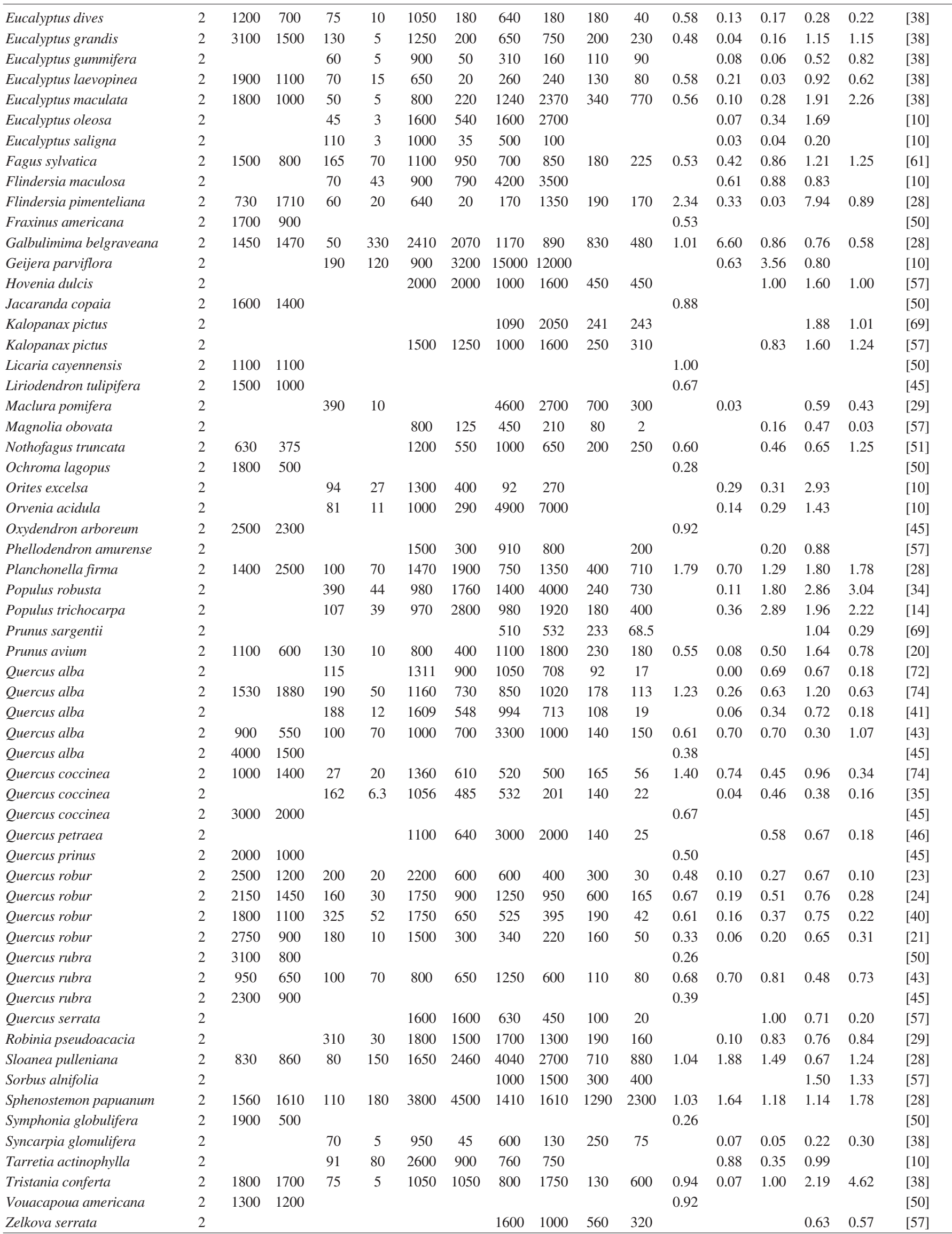

